\title{
Hubungan Hiperglikemia dengan Prothrombin Time pada Mencit (Mus musculus) yang Diinduksi Aloksan
}

\author{
Muhammad Ibnu Malik ${ }^{1}$, Ellyza Nasrul ${ }^{2}$, Asterina $^{3}$
}

\begin{abstract}
Abstrak
Diabetes mellitus mempunyai dua macam komplikasi yaitu komplikasi akut dan kronik. Komplikasi kronik DM (mikroangiopati dan makroangiopati) terjadi akibat disfungsi endotel yang disebabkan oleh berbagai proses pathogenesis yaitu hiperglikemia, stres oksidatif, peningkatan jumlah asam lemak bebas, Protein Kinase $C \beta$ dan defek sekresi insulin. Kerusakan pembuluh darah (disfungsi endotel) tersebut dapat dideteksi melalui pemeriksaan activated partial prothrombin time (APTT) dan prothrombin time (PT) yang berperan dalam mekanisme homeostasis padatubuh.Tujuan penelitian ini adalah untuk melihat hubungan hiperglikemia dengan prothrombin time pada mencit putih (Musmusculus) yang diinduksi aloksan. Desain penelitian ini adalah post test only control group design yang dilaksanakan dari Oktober 2013 hingga Februari 2014 di Laboratorium Sentral RS. Dr. M. Djamil Padang. Subjek penelitian adalah mencit putih (Musmusculus) yang telah memenuhi criteria inklusi dan eksklusi, kemudian dibagi menjadi kelompok hiperglikemia (diinjeksikan aloksan) dan kelompok kontrol. Setelah adaptasi selama tujuh hari, dilakukan injeksi aloksan serta pemeriksaan glukosa darah dan berat badan tiap empat hari sekali. Pada hari ke 30 dilakukan terminasi untuk mengukur PT mencit. Hasil menunjukkan terdapat pemendekan PT pada kedua kelompok penelitian dengan rerata PT kelompok control adalah 7,96 detik dan kelompok hiperglikemia adalah 8,12 detik. Hasil pengukuran tersebut menunjukkan tidak terdapat hubungan antara hiperglikemia dan prothrombin time $(p>0,05)$.
\end{abstract}

Kata kunci: hiperglikemia, diabetes mellitus, prothrombin time, aloksan.

\begin{abstract}
Diabetes mellitus have two complication, they are acute and chronic complication. Chronic complication of $D M$ (microangiopathy and macroangiopathy) accured because endotel dysfunction which caused by various pathogenesis, such as hyperglycemia, oxydative stress, upregulation of free fatty acid, Protein Kinase $C \beta$ and insulin secretion defect. Endothelial disfungtion can be detected by activated partial thromboplastin time (APTT) and prothrombin time (PT). The objective of this studi was to determine the correlation between hyperglycemia and prothrombin time in mice (Mus musculus) induced with aloxan. The design of this research was a post test only control group design conducted in October 2013 until February 2014 in Central Laboratory RS Dr. M. Djamil Padang. The subject were white mice (Mus musculus) who have met the inclusion and exclusion criteria. The subject were divided as hyperglycemia group (induced with aloxan) and control group. After seven days of adaptation, the aloxan was injected and measurenment of blood glucose and body weight had been done, one time in every four days. Then in day 30th the termination of mice had been done to meassure the prothrombin time. The result showed the prothrombin time between group was shortened with the average prothrombin time of the control group was 7,96 second and the hiperglicemia group was 8,12 second. The result showing no correlation between hyperglycemia and prothrombin time with the degree of signification is (p) 0,7 $(p>0,05)$.
\end{abstract}

Keywords: hyperglycemia, diabetes mellitus, prothrombin time, aloxan

Affiliasi penulis : 1. Pendidikan Dokter FK UNAND (Fakultas Kedokteran Universitas Andalas Padang), 2. Bagian Patologi Klinik FK UNAND, 3. Bagian Kimia FK UNAND
Korespondensi :Muhammad Ibnu Malik, E-mail:

muhammadibnumalik@gmail.com,Telp: 08981367774 


\section{PENDAHULUAN}

Diabetes mellitus (DM) adalah suatu kelompok penyakit gangguan metabolik yang ditandai dengan peningkatan kadar glukosa darah melebihi normal (hiperglikemia). Hiperglikemia pada DM yang tidak terkontrol dapat menyebabkan kerusakan berat pada jaringan tubuh, seperti saraf dan pembuluh darah. ${ }^{1}$

World Health Organization (WHO) menyatakan terdapat 347 juta orang di dunia didiagnosis mengidap DM. WHO memperkirakan DM akan menjadi penyebab kematian nomor tujuh di seluruh dunia pada tahun 2030. Prevalensi DM di dunia diperkirakan sekitar 6,4\% pada tahun 2010 dan diprediksi meningkat menjadi $7,7 \%$ pada tahun 2030 . Sebagian besar peningkatan prevalensi DM tersebut terjadi di negara berkembang. ${ }^{2}$

Berbagai penelitian epidemiologi mendapatkan prevalensi DM di Indonesia sebesar $1,5 \%-2,3 \%$ pada tahun 1980-an. Menurut data Riskesdas tahun 2007 prevalensi DM mengalami peningkatan yang signifikan yaitu sebesar 5,7\%. Hasil penelitian di Jakarta mendapatkan peningkatan prevalensi DM dari 1,7\% padatahun 1982 dan 5,7\% pada tahun 1993 menjadi 6,6\% pada tahun 2007. Penelitian di Ujung Pandang mendapatkan prevalensi DM meningkat dari 1,5\% pada tahun 1981 menjadi 2,9\% ditahun 1998. Riset Kesehatan Dasar Departemen Kesehatan RI (2007) mendapatkan prevalensi DM tertinggi terdapat di Kalimantan Barat dan Maluku Utara (masing-masing 11,1\%), diikuti Riau $(10,4 \%)$ dan NAD (8,5\%), sedangkan prevalensi DM di Provinsi Sumatera Barat yaitu 4,1\%. Peningkatan prevalensi DM dari tahun ke tahun menunjukkan bahwa DM merupakan masalah kesehatan yang cukup serius di dunia maupun di Indonesia. ${ }^{3,4}$

Keadaan hiperglikemia dan DM dapat mengakibatkan kerusakan sistemik yang luas pada tubuh. Hal ini disebabkan karena terdapat gangguan pada metabolism glukosa, lemak, dan protein sebagai hasil dari defek sekresi insulin maupun gangguan fungsi insulin di perifer. Berbagai komplikasi akut DM yaitu koma hiperglikemia, ketoasidosis dan koma hiperosmolar non-ketotik. ${ }^{5}$ Komplikasi kronik DM mengakibatkan kerusakan pembuluh darah (endotel) meliputi makroangiopati yang mengenai pembuluh darah besar pada jantung serta otak dan mikroangiopati meliputi nefropati dan retinopati. ${ }^{6}$

Stres oksidatif memegang peranan penting terhadap patogenesis berbagai komplikasi makro dan mikroangiopati DM. Hal tersebut terjadi melalui peningkatan berbagai aktifitas metabolik pada DM seperti peningkatan aktivitas jalur polyol, peningkatan produksi produk akhir glikasi (AGEs), protein kinase C (PKC), peningkatan aktivitas nuclear transcription factor $k b$ (NFkb) dan peningkatan aktivitas jalur heksoamin. Berbagai proses metabolism tersebut akan menghasilkan sejumlah besar spesies oksigen dan nitrogen reaktif. Keadaan ini akan diperparah karena terdapat peningkatan kadar free fatty acid dan penurunan produksi antioksidan nitric oxide (NO) sehingga turut mendukung kerusakan pada struktur pembuluh darah.

Endotel pada pembuluh darah yang mengalami kerusakan akan melepaskan molekul factor jaringan (tissue factor/TF) yang dapat mengaktifkan mekanisme pembekuan darah (koagulasi) pada jalur ekstrinsik. Mekanisme koagulasi adalah penting untuk mencegah tubuh kehilangan darah akibat kerusakan pembuluh darah. Mekanisme ini dapat menimbulkan keadaan patologis apabila terus menerus diaktifkan akibat kerusakan pembuluh darah pada banyak tempat. Aktivasi kaskade pembekuan darah yang berlebihan ini dikenal dengan keadaan hiperkoagulasi. $^{7}$ Menurut penelitian hiperkoagulasi pada pasien DM dihubungkan dengan berbagai penyakit kardiovaskular seperti infark miokard, gagaljantungdan stroke. $^{8}$

Selain peningkatan kadar TF, penelitian oleh Heywood menyatakan terdapat juga peningkatan kadar berbagai factor pembekuan pada pasien DM, salah satu faktor pembekuan tersebut ialah Faktor VII. Faktor VII adalah salah satu faktor pembekuan darah yang berperan penting pada jalur ekstrinsik aktivasi pembekuan darah. Peningkatan kadar Faktor VII dan berbagai faktor pembekuan jalur ekstrinsik dapat diketahui melalui pemeriksaan prothrombin time (PT). ${ }^{9,10}$

Penelitian yang pernah dilakukan oleh Zhao dkk pada tahun 2011 membuktikan bahwa terdapat hubungan antara DM dengan pemendekan APTT 
(Activated Partial Thromboplastin Time). APTT adalah pemeriksaan untuk mengetahui mekanisme pembentukan aktivator protrombin melalui jalur intrinsik pembekuan darah. Pemendekan APTT disebabkan terdapat peningkatan kadar berbagai faktor koagulasi yang berperan pada jalur instrinsik, antara lain Faktor XI, Faktor VIII danFaktor IX. ${ }^{11}$

Berdasarkan hal diatas perlu dilakukan penelitian tentang hubungan hiperglikemia terhadap kecepatan pembekuan darah dengan memakai Prothrombin time (PT) sebagai indikator pengukuran. PT digunakan untuk menguji kecepatan pembekuan darah melalui jalur ekstrinsik dan jalur bersama yang melibatkan faktor pembekuan VII, X, V, protrombindan fibrinogen. ${ }^{7}$

\section{METODE}

Jenis penelitian ini adalah penelitian eksperimental laboratories dengan pendekatan post test only control group design. Populasi adalah mencit putih yang tersedia di Laboratorium Farmasi Unand. Sampel penelitian diambil secara acak (random) sehingga didapat untuk tiap kelompok adalah 5 (lima) ekor. Adapun criteria inklusi adalah mencit jantan, umur 6-7 minggu, berat 20-30 gram, tidak ada cacat anatomi atau sakit, sedangkan criteria eksklusi adalah mencit mati. Penelitian dilaksanakan dari Oktober 2013 hingga Februari 2014. Variabel bebas dalam penelitian ini adalah hiperglikemia (mg/dl) dan variabel tergantung adalah PT (detik).

Pengukuran gula darah dilakukan dengan menggunakan Glucocheck, sedangkan pengukuran PT dilakukan secara otomatisasi menggunakan alat Sysmex CA-500 Automatic Blood Coagulation Analizer untuk mengurangi bias selama pengukuran. Mencit yang dipilih secara acak sesuai dengan kriteria inklusi dan eksklusi dibagi menjadi 2 kelompok. Adaptasi dilakukan selama 7 hari dan selama proses adaptasi semua mencit hanya diberi diet standar. Aloksan diinjeksikan pada hari ke 7, 11, 15 dan 19 sebanyak $100 \mathrm{mg} / \mathrm{KgBB}$ intraperitoneal per hari terhadap kelompok perlakuan. Setiap sebelum injeksi aloksan, dilakukan penimbangan berat badan dan pengukuran glukosa darah mencit untuk memastikan efek pemberian aloksan benar-benar menyebabkan hiperglikemia pada mencit. Kemudian pada hari ke 20 hingga 30, kelompok kontrol dan perlakuan hanya diberi diet standar. Hari ke-30 dilakukan pemerikasaan kadar glukosa darah mencit serta pemeriksaan PT mencit di laboratorium sentral RS. Dr. M. Djamil Padang. Setelah itu dilakukan analisis terhadap data yang telah diperoleh secara komputerisasi.

Analisis data dilakukan secara bertahap yaitu dengan melakukananalisisunivariatsertauji normalitas distribusi data. Bila distribusi data normal, maka dipakai uji $t$ untuk melihat hubungan hiperglikemia dengan prothrombin time. Bila data tidak terdistribusi normal, maka dipakai uji Mann whitney.

\section{HASIL}

1. Analisis Univariat

Tabel 1. Berat Badan Awal Mencit

\begin{tabular}{ccc}
\hline No & Kontrol $(\mathrm{n}=6)$ & Perlakuan $(\mathrm{n}=6)$ \\
\hline I & $27 \mathrm{gram}$ & $26 \mathrm{gram}$ \\
II & $20 \mathrm{gram}$ & $24 \mathrm{gram}$ \\
III & $27 \mathrm{gram}$ & $27,5 \mathrm{gram}$ \\
IV & $24 \mathrm{gram}$ & $24,5 \mathrm{gram}$ \\
V & $25,5 \mathrm{gram}$ & $24 \mathrm{gram}$ \\
VI & $27 \mathrm{gram}$ & $24,5 \mathrm{gram}$ \\
Rata-rata & $25,08 \mathrm{gram}$ & $25,08 \mathrm{gram}$ \\
\hline
\end{tabular}

Dari tabel 1 terlihat bahwa karakteristik berat badan awal mencit percobaan mempunyai nilai terendah yaitu 20 gram dan tertinggi yaitu 27,5 gram. Rata-rata berat badan kelompok kontrol dan perlakuan didapatkan sama yaitu 25,08gram.

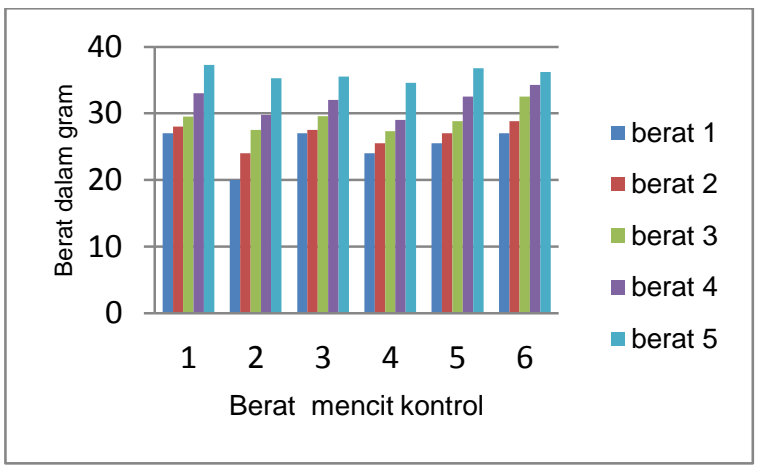

Grafik 1. Perkembangan Berat Badan Mencit Kelompok Kontrol

Grafik 1 dan dan grafik 2 memperlihatkan perkembangan berat bada mencit selama penelitian dilaksanakan. Tampak perbedaan perkembangan 
berat badan yang cukup signifikan antara kelompok kontrol dengan kelompok perlakuan. Rata-rata pertambahan berat badan kelompok kontrol pada setiap kali pengukuran adalah $\pm 9 \%$.

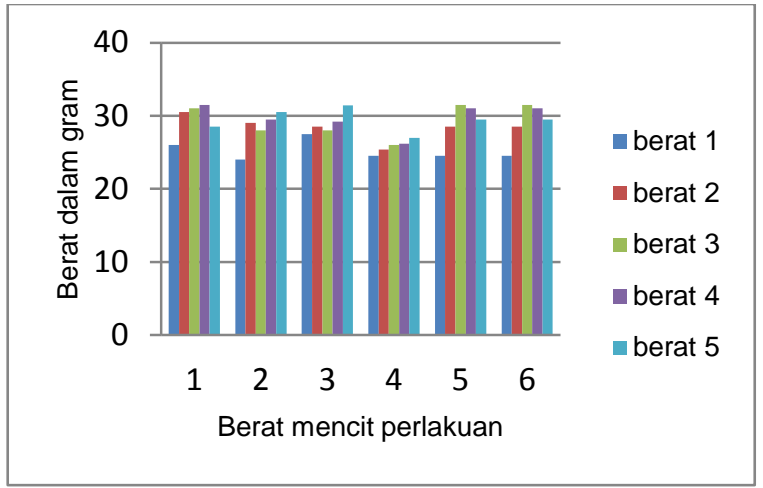

Grafik 2. Perkembangan Berat Badan Mencit Kelompok Perlakuan

Berat badan mencit kontrol mencapai nilai tertinggi pada saat pengukuran ke-5 dengan rerata 35,95 gram. Perubahan berat badan kelompok perlakuan justru tidak menunjukkan peningkatan yang bermakna dan cenderung mengalami penurunan hingga pengukuran yang ke-5. Berat badan tertinggi kelompok perlakuan hanya mencapai 31,5 gram dan rata-rata berat badan mencit pada pengukuran terakhir adalah 29,4 gram.

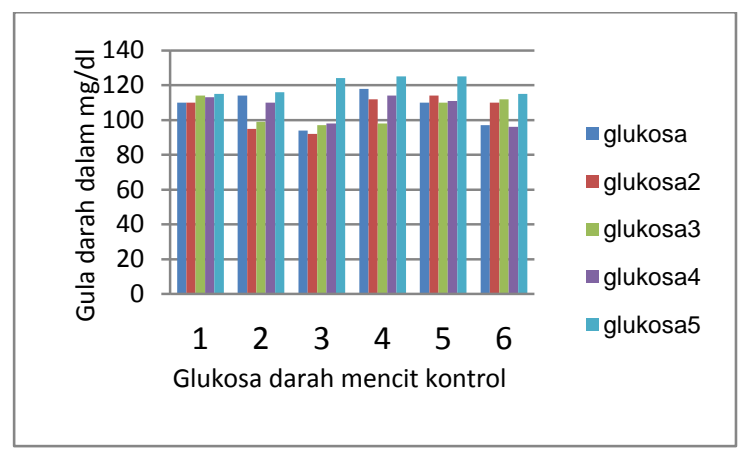

Grafik 3. Perubahan Kadar Glukosa Puasa Kelompok Mencit Kontrol

Dari tabel 4 didapatkan bahwa glukosa puasa kelompok kontrol terpantau stabil (<126 mg/dl) dengan nilai maksimum mencapai $125 \mathrm{mg} / \mathrm{dl}$ pada mencit kontrol 4 dan 5 . Secara keseluruhan didapatkan ratarata glukosa puasa kelompok perlakuan yaitu 108 $\mathrm{mg} / \mathrm{dl}$.

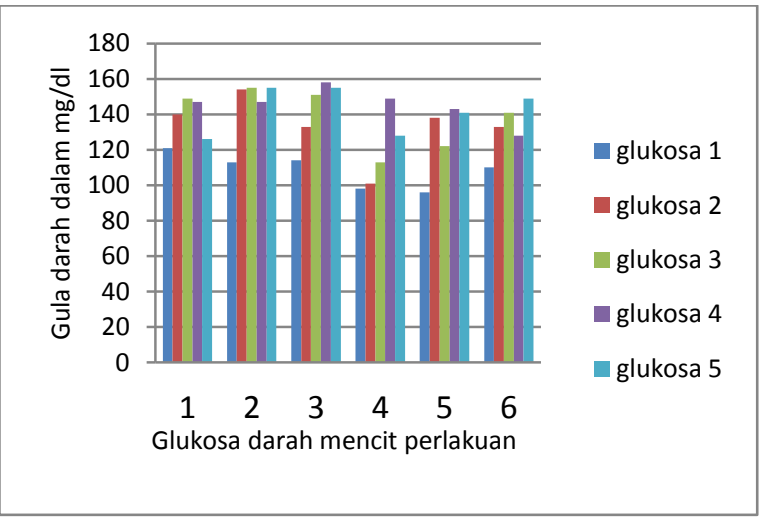

Grafik 4. Perubahan Kadar Glukosa Puasa Kelompok Mencit Perlakuan

Grafik 4 memperlihatkan secara keseluruhan didapatkan rerata glukosa puasa kelompok perlakuan yaitu 108 mg/dl. Nilai glukosa puasa kelompok perlakuan cenderung mengalami peningkatan yang langsung dapat dilihat pada pengukuran ke-2. Glukosa puasa tertinggi dicapai oleh mencit perlakuan 3 dengan kadar $158 \mathrm{mg} / \mathrm{dl}$ (> $126 \mathrm{mg} \mathrm{dl}$ ).

Pada hari ke-30 dilakukan pemeriksaaan PT terhadap kedua kelompok. Sampel yang dibutuhkan yaitu darah mencit $0,8 \mathrm{ml}$ yang diambil melalui metode terminal bleeding (diseksi arteri karotis dan vena jugularis). Hasil pemeriksaan PT dapat dilihat pada tabel 2.

Tabel 2 menunjukkan bahwa seluruh hasil pemeriksaan PT mengalami pemendekan $(\mathrm{PT}<10$ det). Nilai PT terendah dimiliki oleh mencit perlakuan VI dengan nilai PT 7,3 det. Satu buah sampel darah dari masing-masing kelompok mengalami lisis sehingga tidak dapat dilakukan analisis PT.

Tabel 2. Hasil Pengukuran Prothrombin Time Tiap Kelompok Mencit

\begin{tabular}{ccc}
\hline No & $\begin{array}{c}\text { Kelompok kontrol } \\
(\text { det })\end{array}$ & $\begin{array}{c}\text { Kelompok perlakuan } \\
(\text { det })\end{array}$ \\
\hline I & 7,7 & 8,2 \\
II & 8,1 & 7,5 \\
III & 7,4 & Error $^{*}$ \\
IV & 9,2 & 9,5 \\
V & 7,4 & 8,1 \\
\hline VI & Error & 7,3
\end{tabular}

* sampel darah mengalami lisis sehingga tidak dapat dianalisis.

Nilai normal PT: 10-15 det, ( <10 det maka PT = memendek). 


\section{Analisis Bivariat}

Analisis bivariat dilakukan untuk mengetahui hubungan hiperglikemia dengan hasil pemeriksaaan prothrombin time. Langkah pertama yaitu melakukan uji normalitas data melalui uji shapiro wilk. Data terdistribusi normal jika $p>\alpha$ dimana $\alpha=0,05$. Dari hasil uji shapiro wilk, didapatkan nilai (p) 0,391 ( $p>$ $0,05)$ sehingga dapat dikatakan data terdistribusi normal.

Untuk mengetahui hubungan hiperglikemia dengan prothrombin time maka selanjutnya dilakukan uji $\mathrm{t}$ tidak berpasangan(tabel 3). Hasil dianggap bermakna apabila nilai $\mathrm{p}<0,05\left(\mathrm{H}_{0}\right.$ ditolak $)$.

Tabel 3. Hasil Analisis Hubungan Hiperglikemia dengan Prothrombin Time pada Mencit Percobaan

\begin{tabular}{cccc}
\hline & $\mathrm{n}$ & $\begin{array}{c}\text { Mean } \pm \text { std. } \\
\text { deviation }\end{array}$ & $\mathrm{p}$ \\
\hline $\begin{array}{c}\text { Tidak } \\
\text { hiperglikemia }\end{array}$ & 5 & $7,96 \pm 0,75$ & 0,76 \\
Hiperglikemia & 5 & $8,12 \pm 0,86$ &
\end{tabular}

Dari tabel 3 dapat dilihat bahwa dari penelitian ini didapatkan nilai (p) 0,76 ( $p>0,05)$ sehingga dapat disimpulkan bahwa tidak terdapat hubungan signifikan antara hiperglikemia pada mencit (Mus musculus) dengan hasil pemeriksaan prothrombin time $\left(\mathrm{H}_{0}\right.$ diterima).

\section{PEMBAHASAN}

Hasil pengukuran berat badan mencit, didapatkan peningkatan berat badan pada kelompok perlakuan setelah injeksi aloksan yang pertama dilakukan (Grafik 2). Kemudian dari hasil pengukuran kadar glukosa darah mencit didapatkan keadaan hiperglikemia (rata-rata 133,16 mg/dl) pada kelompok perlakuan empat hari setelah injeksi aloksan pertama dilakukan (Grafik 4). Kadar glukosa puasa kelompok perlakuan mencapai puncaknya empat hari setelah injeksi aloksan ke-3 dilakukan.

Pada hari ke-30 dilakukan pemeriksaan PT di Laboratorium RS. M. Djamil padang. Dari 12 sampel darah yang diberikan, dua diantaranya mengalami lisis sehingga jumlah sampel yang dianalisis hanya 10 sampel. Hasil pemeriksaan PT menunjukkan terdapat pemendekan PT pada seluruh mencit kontrol dan perlakuan. Kemudian dilakukan analisis data melalui uji shapiro wilk dan di dapatkan hasil tingkat signifikasi (p) 0,76 ( $p>0,05)$. Ini berarti hipotesis $\mathrm{H}_{0}$ diterima sehingga disimpulkan tidak terdapat hubungan yang signifikan antara hiperglikemia dengan hasil pemeriksaan prothrombin time.

Pada penelitian ini didapatkan pemendekan PT pada mencit kelompok perlakuan dengan rerata 8,12 detik. Kerusakan endotel pada hiperglikemia dipicu oleh mekanisme stres oksidatif akibat peningkatan aktivitas glikasi dan peningkatan kadar asam lemak bebas (free fatty acid). Aktivitas glikasi yang berlebihan dan peningkatan kadar asam lemak bebas akan menghasilkan produk metabolisme sampingan berupa spesies oksigen reaktif yang dapat merusak membran mitokondria dan membran sel endotel. $^{12}$ Endotel yang rusak akan melepaskan Faktor jaringan yang kemudian akan mengaktifkan Faktor VII. Kemudian Faktor VII bersama ion kalsium akan mengaktifkan Faktor $\mathrm{X}$ yang bersama dengan Faktor $\mathrm{V}$ dan fosfolipid jaringan akan membentuk kompleks aktivator protrombin. $^{7}$

Selain terdapat pemendekan PT pada kelompok mencit perlakuan, pemendekan PT juga terjadi pada kelompok kontrol dengan rerata PT 7,96 detik. Hal ini disebabkan oleh pertambahan berat badan mencit kontrol akibat pengaruh pemberian diet secara ad libitum. Hasil pemantauan berat badan mencit kelompok kontrol mendapatkan peningkatan yang signifikan bila dibandingkan dengan kelompok perlakuan. Hal tidak ditemukan pada kelompok perlakuan akibat defek sekresi insulin akibat injeksi aloksan. Kekurangan kadar insulin menyebabkan sejumlah besar glukosa tertahan di ekstra sel sehingga sel mengalami krisis energi. Hal tersebut akan merangsang sel untuk mengambil energi dengan cara memecah lemak (trigliserida). Lemak dipecah menjadi gliserida dan asam lemak bebas. Bila terus berlanjut, jumlah simpanan lemak tubuh akan berkurang sehingga tubuh akan kehilangan berat badan. Keadaan ini bisa kita temukan pada penderita diabetes mellitus tipe 1.,13

Hasil ini sesuai dengan penelitian Volz et al pada tahun 1978 yang melakukan penelitian terhadap tikus yang diberi pakan 3 kali/hari dan tikus yang diberi pakan secara ad libitum selama 120 hari. Volz et al 
mendapatkan pemberian pakan secara ad libitum dapat meningkatkan pertambahan berat badan tikus hingga $50 \%$ akibat peningkatan simpanan lemak dalam tubuh dengan tingkat signifikasi $(p)<0,01$. $^{14}$

Hal di atas juga sesuai dengan penelitian Singh et al pada tahun 2012 yang mendapatkan bahwa peningkatan berat badan melebihi BMI normal dapat mengakibatkan peningkatan kadar Faktor VII yang berperan pada aktivasi jalur ektrinsik pembekuan darah. Hasil pemeriksaan kadar Faktor VII oleh Singh et al mendapatkan kadar Faktor VII pada sampel anak sehat adalah 0,90 $\pm 0,20 \mathrm{u} / \mathrm{ml}$ sedangkan pada anak obese sebesar 1,03 $\pm 0,20 \mathrm{u} / \mathrm{ml}$ dengan (p) 0,032 (p< 0,05). Peningkatan kadar Faktor VII tersebut akanmeningkatkan pembentukan trombin dalam pembuluh darah sehingga hasil pemeriksaan PT dapat memendek. ${ }^{15}$ Hasil ini sesuai juga dengan penelitian yang dilakukan oleh oleh Noriyuki dkkpada tahun 2013 terhadap sampel mencit kurus dan mencit obese. Setelah dilakukan pemeriksaan PT terhadap kedua kelompok perlakuan, Noriyuki et al mendapatkan hasil pemeriksaan PT yang memendek pada kelompok mencit obese dengan tingkat signifikasi $p<0,01$. $^{16}$

Terdapat beberapa faktor yang mempengaruhi pertambahan berat badan mencit, antara lain jumlah pakan yang diberikan (ad libitum atau tidak), jenis pakan yang diberikan, kebersihan kandang mencit dan tingkatan stres mencit. Penelitian ini belum dapat mengantisipasi faktor-faktor tersebut karena keterbatasan waktu dan biaya.

\section{KESIMPULAN}

Terdapat pemendekan prothrombin time pada mencit kelompok perlakuan ( $<10$ detik), namun hal yang sama juga ditemukan pada kelompok kontrol.

Didapatkan bahwa tidak terdapat hubungan hiperglikemia dengan prothrombin time dengan taraf signifikasi $(p) 0,76(p>0,05)$.

\section{UCAPAN TERIMAKASIH}

Ucapan terimakasih yang sedalam-dalamnya kepada Prof. DR. dr. Ellyza Nasrul, SpPK(K) dan Dra. Asterina, MS atas bimbingan, arahan dan motivasi dalam penelitian ini.

\section{DAFTAR PUSTAKA}

1. A Icks, B Haastert, C Trautner, G Giani, G Glaeske, F Hoffman. Incidence of lower-limb amputations in the diabetic compared to the nondiabeticpopulation, Findings from nationwide insurance data, Germany 20052007.Experimental and ClinicalEndocrinology \& Diabetes. 2009;117: 500-4.

2. Shaw JE, Sicree RA, Zimmet PZ. Global estimates of the prevalence of diabetes for 2010 and 2030. Diabetes Research and Clinical Practice. 2010;87(1): 4-14.

3. Riset Kesehatan Dasar. Badan Penelitian dan Pengembangan Kesehatan. Departemen Kesehatan Republik Indonesia; 2007.

4. Suyono S. Diabetes mellitus di Indonesia, Dalam: Buku Ajar IImu Penyakit Dalam Jilid III. Edisi ke5. Jakarta: Interna Publishing; 2009. hIm. 1873-9.

5. Soewondo P. Ketoasidosis Diabetik. Dalam: Buku Ajar IImu Penyakit Dalam Jilid III. Edisi ke-5. Jakarta: Interna Publishing; 2009. hlm. 1906-10

6. Waspadji S. Komplikasi kronik diabetes : mekanisme terjadinya, diagnosis dan strategi pengelolaan. Dalam: Buku Ajar IImu Penyakit Dalam. Edisi ke-5. Jakarta : Interna Publishing; 2009. hlm. 1922-9.

7. Guyton AC, Hall JE. Hemostasis dan pembekuan darah. Dalam: Fisiologi Kedokteran. Edisi ke-11. Jakarta: EGC; 2007. hlm. 480-91.

8. Karatela RA, Sainani GS. Interrelationship between coagulation factor VII and obesity in diabetes mellitus (type 2). Diabetes Research and Clinical Practice. 2009;84(3): 41-4.

9. Heywood DM, Mansfield MW, Grant PJ. Factor VII gene polymorphisms, factor VII: C levels and features of insulin resistance in non-insulindependent diabetes mellitus.Thrombosis and Haemostasis. 1996;75 (3): 401-6.

10. Bakta IM. Hematologi klinik ringkas. Jakarta: EGC; 2012. hlm. 233-54.

11. Zhao Y, Zhang J, Zhang J, Wu J. Diabetes mellitus is associated with shortened activated partial thromboplastin time and increased fibrinogen values. Plos ONE. 2011 (diunduh 20 
November 2013). Tersedia dari: URL: HYPERLINK http://www.plosone.org/article/ info \%3Adoi\%2F10.1371\%2Fjournal.pone. 0016470.

12. Johansen JS, Harris AK, Rychly DJ, Ergul A. Oxidative stress and the use of antioxidants in diabetes: Linking basic science to clinical practice. Cardiovasc Diabetol. 2005;4: 5-16.

13. American Diabetes Association. Diabetes mellitus. (diunduh 1 Maret 2014).Tersedia dari: URL: HYPERLINK http://www.diabetes.org/ diabetes-basic/symptoms/.

14. Volz Leo J, Richard A. Ahrens. A three-meal-aday dietary pattern versus ad libitum food intake in albino rats. Department of food, Nutrition and
Institution Universuty of Maryland. J. Nutr. 1978; 1033-8.

15. Singh Anamika, Gary D. Foster, Jay Gunawardana, Tara Alexis Mc Coy et al.Elevated Circulating Tissue Factor Procoagulant Activity, Factor VII, and Plasminogen Activator Inhibitor-1 in Childhood Obesity: Evidence of a Procoagulant State. NIH Public Acces. 2012;158(4): 523-7.

16. Noriyuki K, Dai N, Shin-ichi H, Saya Takahashi, Motoi Kuratani, Norihiko Hirai, et al. Shortened Blood Coagulation Times in Genetically Obese Rats and Diet - Induced Obese Mice. J-STAGE. 2013;75(9): 1245-8. 